\title{
Małgorzata Bogunia-Borowska, Reklama jako tworzenie rzeczywistości społecznej, Kraków 2004, ss. 161.
}

Autorka książki Małgorzata Bogunia-Borowska jest doktorem socjologii Uniwersytetu Jagiellońskiego w Krakowie. Jej zainteresowania naukowe oscylują w kręgu socjologii kultury, teorii kultury i telewizji. Książka pod tytułem Reklama jako tworzenie rzeczywistości społecznej jest pracą doktorską Autorki napisaną w 2004 roku, poświęconą analizie telewizyjnych przekazów reklamowych. Oparta jest ona na teoriach społecznego konstruowania rzeczywistości, habitusie i koncepcji praktyk społecznych. Autorka próbuje dopasować te teorie do przekazu reklamowego, co nie zawsze jej się udaje. Już na samym wstępie próbuje pokazać nam, że reklama zmienia rzeczywistość społeczną poprzez modyfikację naszej wiedzy potocznej, tworząc nowy porządek społeczny. Ten nowy porządek jest zasługą niezwykle pożytecznej roli, jaką spełnia reklama. Dowiadujemy się również, że reklama pokazuje nam obiektywny świat, dostarczając przeżyć i wiedzy potocznej ${ }^{1}$. Powyższe stwierdzenie jest banałem. Reklama nigdy nie przekazuje obiektywizmu, to co widzimy jest zawsze subiektywne, a zmiana rzeczywistości dokonywana przez reklamę może polegać tylko na tym, że świat jest bardziej kolorowy, a nie na dokonaniu rewolucji w porządku społecznym. Poza tym nie zawsze i nie w każdym miejscu, zamieszczenie kolorowej reklamy możemy nazwać jej pożytecznym działaniem. Jako żart możemy uważać stwierdzenie o pokazywaniu obiektywnego świata przez reklamę i dostarczaniu przez nią wiedzy potocznej. Reklama może nam dostarczać tylko nowych stylów życia ${ }^{2}$, a nie wiedzy, która nas przez życie poprowadzi. Nie wiadomo co Autorka rozumie pod określeniem wiedza potoczna. Chyba próbuje nas nakłonić, abyśmy poddali się manipulacyjnemu działaniu reklamy, a takie postępowanie jest już nieetyczne w stosunku do społeczeństwa, tym bardziej, że przekazy reklamowe w dzisiejszym świecie stają się coraz bardziej agresywne ${ }^{3}$.

M. Bogunia-Borowska, opisując rzeczywistość medialną, daje nam do zrozumienia, że jest ona rzeczywistością obiektywno-naturalną, a człowiek przyjeżdżający do obcego kraju, pierwsze co robi to ogląda reklamy w celu zdobycia wiedzy o charakterze społecznym i kulturowym ${ }^{4}$. Jest to zupełna ironia dotycząca jednostki ludzkiej. Czyżby człowiek będąc w Egipcie zwracał uwagę na reklamy, a nie na piramidy? Możemy w tej książce również przeczytać, że ludzie pod

${ }^{1}$ Mass media nie odtwarzają świata, tylko go wytwarzają; A. Kozłowska, Oddziaływanie mass mediów, Warszawa 2006, s. 79.

2 M. Golka, W cywilizacji konsumpcyjnej, Poznań 2004, s. 18.

3 J. Olędzki, Media reklama i public relations w Polsce, Warszawa 2005, s. 143.

${ }^{4}$ Reklama przecież nie pokazuje, tylko wskazuje, jak również nie informuje, tylko sugeruje; M. Laszczak, Psychologia przekazu reklamowego, Kraków 2000, s. 181. 
wpływem reklamy zmieniają treści swojego habitusu ${ }^{5}$. Jest to rzeczą niemożliwą, żeby reklama w dzisiejszym świecie, przesyconym tą formą promocji, miała tak wielki wpływ i mogła zmienić nasze mocno zakorzenione działania. Pisząc o człowieku, który jest aktywnym poszukiwaczem nowej wiedzy i informacji, próbuje sprowadzić te zagadnienia do reklamy. W rzeczywistości wiedzę i informacje zdobywamy raczej z innych mediów, a reklama może być tylko dodatkiem. Autorka nazywa reklamę medialną encyklopedią współczesności. To już jest o krok za daleko, a twierdzenie że reklama daje nam wiedzę ogólnospołeczną i usprawnia komunikację międzyludzką jest wielkim błędem. Raz dowiadujemy się o wiedzy encyklopedycznej, którą daje nam reklama, a w innym miejscu wiedza ta jest zawężona tylko do wiedzy komercyjnej. To samo dotyczy obiektywnego świata pochodzącego z reklamy. Raz dowiadujemy się o pełnym obiektywizmie, który emanuje z siebie reklama, a w innych miejscach o nowych środkach wyrazu, które przekraczają rzeczywistość. Jak widać Autorka błądzi w tych dwóch światach i nie może się zdecydować, który z nich jest dla reklamy tym prawdziwym. Znajdziemy tutaj również stwierdzenie, że reklama pełni funkcję integrującą w społeczeństwie i w sposób egalitarny dystrybuuje wiedzę. Reklama może ludzi tylko z sobą poróżnić, a nie zintegrować, ponieważ nie wszystkich stać na reklamowane towary. Zintegrować może tylko kłamstwo niesione przez reklamę, które w poszczególnych przypadkach może zjednoczyć krąg odbiorców. Egalitaryzm ${ }^{6}$ również nie ma nic wspólnego z reklamą. Przekaz reklamowy nie jest dla wszystkich równy w odbiorze. Czytając, że reklama zawęża nasze horyzonty myślowe, momentami może się wydawać, że Autorka uważa ogół społeczeństwa za niedouczonych lub nawet niedorozwiniętych umysłowo. Owszem wykorzystywana w reklamie manipulacja lub reklama podprogowa mogą doprowadzić do mylnych przemyśleń i nieprzewidzianych działań. Nie wszyscy jednak ludzie są tak naiwni i bezmyślni, aby dać się wciagnąć w wiry reklamy.

Twierdzenie, że reklama tworzy nam kulturę ${ }^{7}$ jest również przesadzone. Autorka raz pisze, że spoty reklamowe przedstawiają obiektywną rzeczywistość ${ }^{8}$, a w innym miejscu, że reklama wyprzedza tą rzeczywistość i tworzy nową kulturę. Małe dziecko może z reklamy zaczerpnąć pewne wzorce zachowań i stylów,

5 Trudno jest zmienić habitus, jeśli badania wykazują, że większość klientów odczuwa przesyt treściami reklamowymi, a oddziaływanie samej reklamy stopniowo spada; J. Olędzki, Media reklama, op. cit., s. 23.

6 Egalitaryzm - pogląd głoszący, że podstawą sprawiedliwego ustroju społecznego winna być zasada równouprawnienia ekonomicznego, społecznego i politycznego obywateli; Słownik Wyrazów Obcych, Warszawa 2002, s. 269.

7 Reklama tworzy tylko symbole, a jej cel perswazyjny opiera się na tym, co wytworzyła dana, czyli już istniejąca kultura; A. Kozłowska, Reklama - socjotechnika oddziaływania, Warszawa 2001, s. 148.

8 Przekaz reklamowy jest jedynie odbiciem rzeczywistości społecznej, zwierciadłem wzorów i zachowań; ibidem, s. 152. 
ale rozumny, rozwinięty człowiek może ją tylko potraktować jako mały dodatek do codzienności. Te sprzeczności dotyczące rzeczywistego świata pokazywanego w reklamie, pojawiają się w książce wiele razy. Pisząc o tworzeniu przez reklamę rzeczywistości społecznej stwierdza, że ludzie dysponując nowoczesną konsumpcyjną wiedzą mogą tworzyć wspólnotę komunikacyjną która nie ma nic wspólnego z normami i wartościami. Wiedza konsumpcyjna nie wpływa przecież na dobór kręgu przyjaciół i nie jednoczy ludzi ze sobą. Wspólnotę społeczną tworzą przede wszystkim wartości i normy, które Autorka odrzuca.

Został tu również zawarty przebieg badań, które wskazują że najbardziej ceniona w reklamie jest miłość i przebywanie razem. W pewnym sensie jest to prawdą, ale pokazaną bardzo ogólnie. Najważniejszą jednak rzeczą dotyczącą tych elementów reklamy jest fakt, że człowiek stał się bardziej odporny na otaczający go świat reklamy i nikt pod wpływem „czerwonych serduszek” pokazywanych w reklamie, od razu się nie zakocha i nie zmieni swojego życia. Kawa lub czerwone wino opisywane przez Autorkę, bardzo często pokazywane są na tle intymnego, ekskluzywnego klimatu. Ale czy takie reklamy są w stanie zmienić nasz zaplanowany wieczór? Możemy na nie zwrócić uwagę, możemy zapamiętać markę prezentowanego produktu, ale na pewno nie zrobią one rewolty w naszej codzienności. Przeszkód istnieje wiele. Mogą to być: brak czasu, pieniędzy i nie spożywanie tego rodzaju używek. Poza tym, czy kawa i wino są tylko dla wybranych?

Stwierdzenie, że telewizja tworzy relacje społeczno-towarzyskie i rodzinne jest już przekroczeniem pewnych granic. Autorka próbuje tutaj dokonać personalizacji telewizji i uczynić ją najbliższym i niezbędnym towarzyszem człowieka. Na szczęście jej stwierdzenia nie mają nic wspólnego z rzeczywistością, ponieważ coraz więcej ludzi odchodzi od spędzania dłuższego czasu przed telewizorem. Dowiadujemy się również, że reklama pełni w telewizji służbę społeczną, która w ujęciu Autorki polega na dostarczaniu i upowszechnianiu wiedzy. Ta służba społeczna jest dla Małgorzaty Bogunia-Borowskiej szczególnie ważna w stosunku do polskich zmian kulturowych i społecznych. Autorka bardzo mocno obstaje przy pozytywnej funkcji reklamy, zarówno społecznej, jak i kulturowej. Należy jednak zauważyć, że to reklama telewizyjna wyprowadza nas z równowagi i bardzo często stosujemy zapping, aby zmienić program i uniknąc oglądania reklam ${ }^{9}$. W takiej sytuacji trudno jest stwierdzić, abyśmy z reklamy czerpali wzorce społeczne, a tym bardziej kulturowe. Dorośli ludzie w obecnych czasach starają się unikać przekazów reklamowych, zdając sobie sprawę z tego, na czym one polegają. Tylko nieliczni poszukują w reklamie np. nowoczesności, czy opinii lidera. Nie można z zamkniętymi oczami twierdzić, że to reklama zmienia nasz świat i życie. Wydaje się, że Autorka jest krótkowzrocznym analitykiem reklamy i widzi w niej to, co chce zobaczyć. Brakuje jej spojrzenia na reklamę poprzez inne nauki.

9 Reklama jest odpowiedzialna za niski poziom programów telewizyjnych; M. Golka, W cywilizacji konsumpcyjnej, op. cit., s. 131. 
Kolejnym zagadnieniem opisanym w tej książce jest tworzenie rzeczywistości społecznej przez reklamę społeczną. Małgorzata Bogunia-Borowska uważa, że ideowe kampanie społeczne zmieniają naszą rzeczywistość. Na pewno dostarczają nam pewnych informacji, co należy robić i jak postępować, ale ich wpływ na nasze postawy i poglądy nie do końca doprowadza do zmian. Przykładem tego błędnego rozumowania są kampanie dotyczące palenia papierosów i ich szkodliwości. Napisy typu „palenie zabija” nie doprowadziły do rezygnacji z palenia papierosów i nie wpędziły koncernów tytoniowych w kryzys. W tym przypadku lepszym wyjściem stało się podniesienie cen wyrobów tytoniowych, a nie kampanie społeczne. Reklama społeczna doprowadza czasami do powstania tylko iskierki, pod wpływem której wysyłamy SMS-y na konto chorego dziecka. Jej wpływ na nasze życie jest nadal znikomy i w nielicznych przypadkach skłania nas do zmiany trybu życia, czy zainteresowania innymi ludźmi. Jedną z barier jest szybkie tempo życia w skomercjalizowanym świecie ${ }^{10}$.

Po przeczytaniu książki wydaje się, że Autorka próbuje nakłonić nas do częstszego przebywania z reklamą. W rzeczywistości cała publikacja jest wielką pomyłką, której zadaniem jest próba przekonania nas, jak wielką pozytywną rolę spełnia przekaz reklamowy. Odnieść można wrażenie, że Małgorzata Bogunia-Borowska jest zwolenniczką manipulacji reklamowej i pozostaje w zmowie z tymi, którzy tą manipulację tworzą. Stwierdzenie Autorki, że wiedza ogólna, stanowiąca czynnik jednoczący ludzi jest dla nas osiaggalna tylko dzięki reklamie i ciągłe powtarzanie tego jest wielką przesadą.

Robert Grochowski

Gniezno

10 Należy zauważyć, że reklama społeczna może mieć cechy komercyjne i odsuwając nas od zakupu danego produktu, namawiać do zakupu innego; M. Golka, $W c y$ wilizacji konsumpcyjnej, op. cit., s. 128. 